Brazilian Journal

of Chemical

Engineering

\title{
SIMULATION AND EXPERIMENTAL INVESTIGATION OF POWER CONSUMPTION, GAS DISPERSION AND MASS TRANSFER COEFFICIENT IN A MULTI-PHASE STIRRED BIOREACTOR
}

\author{
Yuanfeng Chen $^{1 *}$ \\ ${ }^{1}$ Fujian Provincial Academy of Environmental Science, Fujian, China. E-mail: fjepi@163.com - ORCID: 0000-0002-7756-5902
}

(Submitted: November 5, 2018 ; Revised: February 21, 2019 ; Accepted: April 5, 2019)

\begin{abstract}
Bio-oxidation leaching of refractory gold concentrate was carried out in a typical gas-liquid-solid three-phase stirred bioreactor. The bacteria, which adhered to solid particle surfaces and spread over the liquid phase, require sufficient oxygen and nutrient of carbon and nitrogen, and then the mass transfer rate should be considered. However, the mass transfer coefficient, which could be used to evaluate the mass transfer rate, was determined by gas holdup, bubble diameter and power consumption. Therefore, a three-phase Eulerian equation with k- $\varepsilon$ turbulence model and additional models of two bubble diameter, a torque and a mass transfer coefficient were applied in the simulation. The simulation results were validated with experimental data and used to analyze the spatial distribution of the mass transfer coefficient. The results demonstrated that the simulation and experimental data of Sauter mean bubble diameter and power number were in good agreement and the simulation results of the mass transfer coefficient were agree with the values calculated by an empirical correlation. The Davoody model can be strongly recommended for further simulation of the bubble diameter, and the gas holdup and mass transfer coefficient were very unevenly distributed in the lower zone. Hence, the lower impeller clearance should be considered.

Keywords: Gas holdup; Bubble diameter; Mass transfer coefficient; Multi-phase flow; Refractory gold concentrate.
\end{abstract}

\section{INTRODUCTION}

Bioleaching of refractory gold concentrate was carried out in a stirred bioreactor. The stirred bioreactor is recommended for gas-liquid-solid three phase systems and it is widespread in the hydrometallurgy, fermentation, biological pharmacy, sewage treatment and allied industries (Chisti and Moo-Young 1988). Oxygen, carbon and nitrogen, which are necessary in bioleaching and aerobic process, were always provided by air. The bacteria adhered to solid particle surfaces and spread over the liquid phase, and their growth was restrained by oxygen concentration and nutrient concentration of carbon and nitrogen (Chisti and Jauregui-Haza 2002; Scargiali, et al. 2012; Karimi, et al. 2013; Scargiali, et al. 2014). To provide sufficient oxygen, carbon and nitrogen, mass transfer should be maintained for better performance (Herrera, et al. 1989; Shrihari, et al. 1991; Boon and Heijnen 1998; Nemati, et al. 1998; Hansford and Vargas 2001).

Mass transfer between phases was a limiting step of the overall process rate in most cases and sometimes positive proportional to the mass transfer coefficient $\left(k_{1} a\right)$, which could also be used to evaluate the mass transfer capacity and carry out the design and scale up of bioreactors (Karimi, et al. 2013; Buffo, et al. 2016). Previous documents pointed out that the mass transfer coefficient is determined by specific surface area and liquid mass transfer coefficient (Higbie 1935; Nedeltchev 2003). As we known, specific surface

\footnotetext{
* Corresponding author: Yuanfeng Chen - E-mail: fjepi@163.com
} 
area can be calculated by $\mathrm{a}=6 \varphi_{\mathrm{g}} / \mathrm{d}_{\mathrm{b}}$ and the liquid mass transfer coefficient has a positive relation with energy dissipation $\left(k_{1} \propto \sqrt[4]{\varepsilon}\right)$ (Dhanasekharan, et al. 2005; Kerdouss, et al. 2008). Energy dissipation was proportional to power consumption. Obviously, the mass transfer coefficient was affected by the gas holdup, bubble diameter and power consumption.

In the gas-liquid-solid three phase stirred bioreactor, experiments focused on how solid suspension influences the mass transfer coefficient in the early years (Joosten, et al. 1977), and now it focuses on how to enhance mass transfer (Sedahmed, et al. 2014; Atef, et al. 2015). The simulations of the mass transfer coefficient mainly focused on the gas-liquid two phase stirred reactor (Ljungqvist and Rasmuson 2001; Kerdouss, et al. 2008), and the simulations of the gas-liquid-solid three phase stirred reactor mainly focused on the solid suspension (Murthy, et al. 2007; Panneerselvam, et al. 2008; Xu, et al. 2012). A handful of documents extended the application of the multiphase simulation to the bubble diameter (Yang, et al. 2016; Zheng, et al. 2018; Zheng, et al. 2019). In this manuscript, the mass transfer coefficient and its influence on the power consumption, gas holdup and bubble diameter were studied based on experiments and simulations. Then, how the aeration rate and solid concentration influenced these factors in a state of just suspension were discussed based on the multi-Euler equation and standard $\mathrm{k}-\varepsilon$ model.

\section{EXPERIMENTAL DETAILS}

\section{Experimental setup}

Experiments were carried out in a stirred bioreactor, which was a cylindrical flat bottom vessel. The reactor was configured with 4 baffles and made of Plexiglas. Its diameter $(\mathrm{T})$ was $226 \mathrm{~mm}$ and height $(\mathrm{H})$ was 500 $\mathrm{mm}$. A ring sparger, of diameter $\mathrm{T} / 2$, was mounted with a clearance of $40 \mathrm{~mm}$. A radial impeller (HEDT) of diameter $100 \mathrm{~mm}$ was installed with a clearance of $\mathrm{T} / 3$ and driven by a variable speed AC motor. The agitation speeds were noted using a tachometer. The bubble parameters were measured with a calibrated conductivity probe (BVW-2 four-channel), which was provided by the Institute of Process Engineering, Beijing, China. The torques were obtained from a torque meter (LONGLV-WTQ1050D-5Nm), which was installed vertically for connecting the agitator shaft and AC motor, and made by Shanghai Longlv Journey Electronic Technology Co. LTD. Water $\left(\rho_{1}=1000 \mathrm{~kg} /\right.$ $\mathrm{m}^{3}$ ) as the liquid phase, refractory gold concentrate $\left(\rho=3548.2 \mathrm{~kg} / \mathrm{m}^{3}\right.$, average diameter is $\left.45.42 \mu \mathrm{m}\right)$ as the solid phase and air as the gas phase were used in the multiphase experiments. A schematic diagram for experiments is pictured in Fig.1.

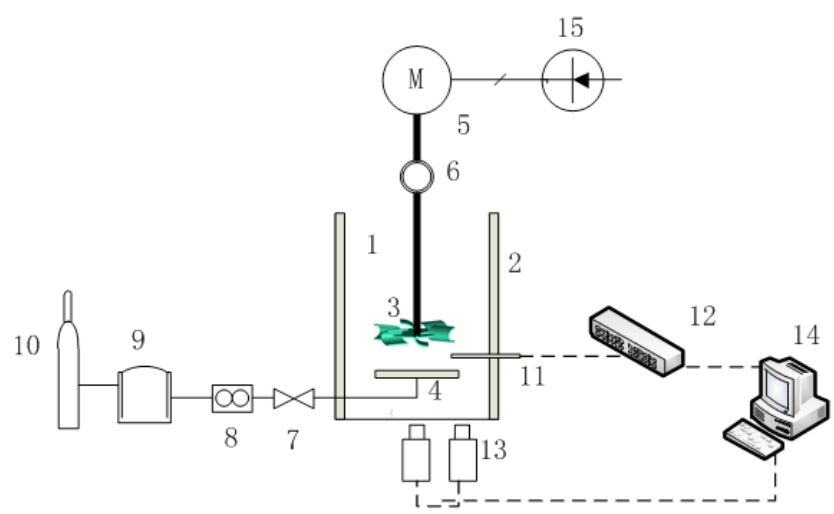

Figure 1. Experimental setup (1: Reactor; 2: Baffle; 3: Impeller; 4: Ring sparger; 5: AC motor; 6: Torque sensor; 7: Gas valve; 8: Rota meters; 9: Gas buffer tank; 10: Gas bottle; 11: Conductivity probe; 12: Data collector; 13: Cameras; 14: Computer; 15: Frequency converter).

\section{Experimental procedure}

Water was first added to the stirred bioreactor, and then 4 weights of solid particles were prepared for different concentrations of 5, 10, 15 and $20 \mathrm{wt} \%$. Air was admitted to the reactor via a ring sparger when the experiments were carried out as follows:

(1) First, the slurry of $5 \mathrm{wt} \%$ was prepared. The air from the gas bottle 10 was admitted to the reactor 1 via the ring sparger 4 , and then adjusted via the gas valve 7 to control the aeration rate at 3 levels of 4,8 and $12 \mathrm{~L} / \mathrm{min}$. The just-suspension speed was obtained by observing visually via the cameras 13 , which was focused on the reactor bottom and provided that the solid particles remained at the reactor bottom for no more than $2 \mathrm{~s}$. The torque was measured by the torque meter.

(2) Secondly, adjusted the probe depth, voltage signals were recorded with a BVW-2-4-CH equipment, and then the voltage signals changed to the local gas holdup and bubble diameter data with the manufacturer-supplied software.

(3) Thirdly, the slurry concentration was gradually increased to 10,15 and $20 \mathrm{wt} \%$, and the steps (1)-(2) repeated to obtain the data of just suspension, power consumption, gas holdup and bubble diameter were obtained.

\section{Data processing}

In the mass transfer process, specific surface area, which directly determines the mass transfer coefficient, is inversely proportional to the bubble diameter. Obviously, in the multiphase stirred bioreactor, the bubble diameter is one of the key factors. Calderbank (1958) proposed that the Sauter mean bubble diameter $\mathrm{d}_{\mathrm{b}, 32}$ could be calculated by,

$$
\mathrm{d}_{\mathrm{b}, 32}=\frac{\sum \mathrm{d}_{\mathrm{u}}^{3}}{\sum \mathrm{d}_{\ddot{\mathrm{u}}}^{2}}
$$


where, $\mathrm{d}_{\mathrm{b}}$ is the bubble diameter.

Power consumption is another one of the key factors in a stirred bioreactor, because more power input via the impeller agitator could directly reduce the bubble diameter and improve the mass transfer coefficient. Power consumption can be obtained from torque $\mathrm{T}_{\mathrm{a}}$ and impeller speed $\mathrm{N}$,

$\mathrm{P}=2 \pi \mathrm{NT}_{\mathrm{a}}$

Under just suspension conditions in the gas-liquidsolid three phase stirred bioreactor, the impeller speeds were not constant. Power number $\left(\mathrm{N}_{\mathrm{p}}\right)$ is a suitable indicator to evaluate power consumption. The power number $\mathrm{N}_{\mathrm{P}}$ could be calculated from the power consumption $\mathrm{P}$,

$$
\mathrm{N}_{\mathrm{P}}=\frac{\mathrm{P}}{\rho_{\mathrm{m}} \mathrm{N}^{3} \mathrm{D}^{5}}
$$

where $\mathrm{N}$ is impeller speed, $\mathrm{D}$ is impeller diameter, $\rho_{\mathrm{m}}$ $=\rho_{1}\left(1-\phi_{1}\right)+\rho_{s} \phi_{s}$ is slurry density.

Chandrasekharan and Calderbank (1981) suggested that the mass transfer coefficient in the three phase stirred bioreactor could be estimated as follows:

$$
\overline{\mathrm{k}_{\mathrm{l}} \mathrm{a}}=\frac{0.0248}{\mathrm{~T}^{4}}\left(\frac{\mathrm{P}}{\mathrm{V}}\right)^{0.551} \mathrm{Q}_{\mathrm{m}}^{0.551 / \sqrt{\mathrm{T}_{\mathrm{m}}}}
$$

where $\mathrm{T}$ is impeller diameter, $\mathrm{P}$ is power consumption, $\mathrm{V}$ is liquid volume, $\mathrm{Q}_{\mathrm{m}}$ is aeration rate. In this equation, SI units are required.

\section{MODEL DESCRIPTION}

There is a lot of literature on simulating the gasliquid two phase stirred bioreactor (Khopkar, et al. 2003; Gentric, et al. 2005; Ding, et al. 2010). However, CFD applications on the gas-liquid-solid three phase stirred bioreactor are still rare (Murthy, et al. 2007; Panneerselvam, et al. 2008; Xu, et al. 2012; Yang, et al. 2016). The Multi-Euler equation was confirmed as the proper way to describe flow behavior of each phase, in which gas, liquid and solid were all treated as continuous phases, penetrating and interacting with each other everywhere in the computational domain (Murthy, et al. 2007; Panneerselvam, et al. 2008; Inc 2013). Turbulence in the dispersed phases of gas and solid could be ignored in the three phase stirred bioreactor, and the standard k- $\varepsilon$ model was proper for simulating turbulence of the liquid phase (Elghobashi and Abou-Arab 1983). The models were founded as follows:

(1) Continuity equation

$$
\frac{\partial}{\partial \mathrm{t}}\left(\varphi_{\mathrm{i}} \rho_{\mathrm{i}}\right)+\nabla \cdot\left(\varphi_{\mathrm{i}} \rho_{\mathrm{i}} \overline{\mathrm{u}}_{\mathrm{i}}\right)=0
$$

(2) Momentum transfer equation

$\frac{\partial}{\partial \mathrm{t}}\left(\varphi_{\mathrm{i}} \rho_{\mathrm{i}} \overline{\mathrm{u}}_{\mathrm{i}}\right)+\nabla \cdot\left(\varphi_{\mathrm{i}} \rho_{\mathrm{i}} \overline{\mathrm{u}}_{\mathrm{i}} \overline{\mathrm{u}}_{\mathrm{i}}\right)=-\varphi_{\mathrm{i}} \nabla \mathrm{P}+\nabla \cdot \tau_{\mathrm{i}}+\varphi_{\mathrm{i}} \rho_{\mathrm{i}} \mathrm{g}+\mathrm{F}_{\mathrm{i}}$

(3) k equation

$$
\frac{\partial}{\partial \mathrm{t}}\left(\varphi_{1} \rho_{1} \mathrm{k}_{1}\right)+\nabla \cdot\left(\varphi_{1}\left(\rho_{1} \overline{\mathbf{u}}_{1} \mathrm{k}_{1}-\left(\mu_{\mathrm{vl}}+\frac{\mu_{\mathrm{tl}}}{\delta_{\mathrm{kl}}}\right) \nabla \mathrm{k}_{1}\right)\right)=\varphi_{1}\left(\mathrm{P}_{1}-\rho_{1} \varepsilon_{1}\right)
$$

(4) $\varepsilon$ equation

$\frac{\partial}{\partial t}\left(\varphi_{1} \rho_{1} \varepsilon_{1}\right)+\nabla \cdot\left(\varphi_{1}\left(\rho_{1} \bar{u}_{1} \varepsilon_{1}-\left(\mu_{\mathrm{vl}}+\frac{\mu_{\mathrm{ul}}}{\delta_{\mathrm{al}}}\right) \nabla \varepsilon_{1}\right)\right)=\varphi_{1} \frac{\varepsilon_{1}}{\mathrm{k}_{1}}\left(\mathrm{C}_{\varepsilon 1} \mathrm{P}_{1}-\mathrm{C}_{\varepsilon 2} \rho_{1} \varepsilon_{1}\right)$

where $\sum_{\mathrm{i}} \varphi^{\mathrm{i}}=1, \tau_{\mathrm{i}}=\varphi_{\mathrm{i}} \mu_{\text {effi, }}\left(\nabla \overline{\mathrm{u}}_{\mathrm{i}}+\left(\nabla \overline{\mathrm{u}}_{\mathrm{i}}\right)^{\mathrm{T}}\right), \mathrm{i}=\mathrm{g}, 1, \mathrm{~s}, \mathrm{~F}_{\mathrm{g}}=$ $-\mathrm{F}_{\mathrm{D}, \mathrm{lg}}, \mathrm{F}_{1}=\mathrm{F}_{\mathrm{T}, \mathrm{l}}+\mathrm{F}_{\mathrm{D}, \mathrm{lg}}+\mathrm{F}_{\mathrm{D}, \mathrm{ls}}, \mathrm{F}_{\mathrm{s}}=-\mathrm{F}_{\mathrm{D}, \mathrm{ls}}-\nabla \mathrm{P}_{\mathrm{s}}, \mathrm{C}_{\varepsilon 1}=1.44$, $\mathrm{C}_{\varepsilon 2} \stackrel{\mathrm{D}, \mathrm{g}}{=} 1.92, \delta_{\mathrm{kl}}=1.0, \delta_{\varepsilon 1}=1.3$. forces,

The turbulence production of viscous and buoyancy

$$
\mathrm{P}_{1}=\mu_{\mathrm{t} 1} \nabla \mathrm{u}:\left(\nabla \mathrm{u}+(\nabla \mathrm{u})^{\mathrm{T}}\right)-\frac{2}{3} \nabla \cdot \mathrm{u}\left(3 \mu_{\mathrm{tl}} \nabla \cdot \mathrm{u}+\rho_{\mathrm{l}} \mathrm{k}_{1}\right)
$$

The additional solids pressure caused by solids collision (Bouillard, et al. 1989),

$\nabla \mathrm{P}_{\mathrm{s}}=\mathrm{G}_{0} \exp \left(\mathrm{c}\left(\varphi_{\mathrm{s}}-\varphi_{\mathrm{sm}}\right)\right) \nabla \varphi_{\mathrm{s}}$

where, $\mathrm{G}_{0}=1.0 \mathrm{~Pa}, \mathrm{c}=600, \varphi_{\mathrm{sm}}=0.376$.

The turbulence dispersion force (Barrue, et al. 2001),

$\mathrm{F}_{\mathrm{Tl}}=-\mathrm{C}_{\mathrm{Tl}} \rho_{1} \mathrm{k}_{1} \nabla \varphi_{1}$

The interchange forces of drag and lift (Montante, et al. 2001; Khopkar, et al. 2005),

$\mathrm{F}_{\mathrm{D}, \mathrm{li}}=\frac{3}{4} \frac{\mathrm{C}_{\mathrm{D}, \mathrm{li}}}{\mathrm{d}_{\mathrm{j}}} \rho_{\mathrm{l}} \varphi_{\mathrm{i}}\left|\overline{\mathrm{u}}_{\mathrm{i}}-\overline{\mathrm{u}}_{1}\right|\left(\overline{\mathrm{u}}_{\mathrm{i}}-\overline{\mathrm{u}}_{1}\right)$

where, $j=b, p$ while $i=g, s$ respectively.

The drag coefficient could be calculated by (Bakker and Vandenakker 1994; Brucato, et al. 1998),

$$
\mathrm{C}_{\mathrm{D}, \mathrm{li}}=\mathrm{C}_{\mathrm{D} 0}\left(1+\mathrm{K}_{\mathrm{i}}\left(\frac{\mathrm{d}_{\mathrm{j}}}{\lambda}\right)^{3}\right)
$$

where $\mathrm{K}_{\mathrm{s}}=8.67 \times 10^{-4}, \mathrm{~K}_{\mathrm{g}}=6.5 \times 10^{-6}$. 
Interaction coefficient between gas and liquid,

$\mathrm{C}_{\mathrm{D} 0}=\max \left(\frac{24}{\operatorname{Re}}\left(1+0.15 \mathrm{Re}_{\mathrm{b}}^{0.687}\right), \frac{2.667 \mathrm{Eo}}{\mathrm{Eo}+4.0}\right)$

Interaction coefficient between liquid and solid (Khopkar and Ranade 2006),

$\mathrm{C}_{\mathrm{D} 0}=\frac{24}{\operatorname{Re}_{\mathrm{p}}}\left(1+0.125 \mathrm{Re}_{\mathrm{p}}^{0.72}\right)$

where, Eotvos number Eo $\left.=g\left(\rho_{1}-\rho_{\mathrm{g}}\right) \mathrm{d}_{\mathrm{b}}{ }^{2}\right) / \sigma, \sigma$ is the surface tension of the gas.

\section{Power number and torque}

Under just suspension conditions in the gas-liquidsolid three-phase stirred bioreactor, the impeller speeds were not constant. Power number $\left(\mathrm{N}_{\mathrm{p}}\right)$, which should be employed to evaluate power consumption, could be calculated by eq.(3). The torque could be calculated from each finite element of the pressure difference between the front and back of the impeller blade $(\Delta \mathrm{P})_{\mathrm{i}}$, distance from the shaft $\mathrm{r}_{\mathrm{i}}$ and the area of the finite element $A_{i}$ (Zadghaffari, et al. 2009),

$\mathrm{T}_{\mathrm{a}}=\sum_{\mathrm{i}}(\Delta \mathrm{P})_{\mathrm{i}} \mathrm{A}_{\mathrm{i}} \mathrm{r}_{\mathrm{i}}$

\section{Bubble diameter}

Although the PBM bubble diameter models are widely applied on the stirred reactor and bubble column (Wang and Wang 2007; Akbari, et al. 2015; Buffo, et al. 2017; Guo, et al. 2017), the various problems were still unresolved. Hence, in this manuscript, simple models were suggested. Hinze (1955) provided the maximum bubble diameter formula based on the hydrodynamic mechanism, as proposed by Zhang, et al. (2013),

$d_{b, \max }=0.725 \sigma^{0.6} \rho^{-0.6} \varepsilon^{-0.4}$

Yang, et al. (2016) recommended that the bubble diameter could be calculated by,

$d_{b}=0.68 d_{b, \max }$

where $\rho$ is density, $\varepsilon$ is turbulence energy dissipation rate. Zheng, et al. (2019) adopted this model to calculate the mass transfer coefficient. Zheng, et al. (2018) also suggested the model amended by Davoody, et al. (2016),

$d_{b, 32}=1.98 \varphi_{\mathrm{g}}^{0.5} \rho^{-0.6} \varepsilon^{-0.4} \sigma^{0.6}+0.0015$

where $\varphi_{\mathrm{g}}$ is gas holdup, $\rho=\varphi_{\mathrm{g}} \rho_{\mathrm{g}}+\varphi_{\mathrm{g}} \rho_{\mathrm{l}}+\varphi_{\mathrm{s}} \rho_{\mathrm{s}}$ is slurry density, $\varepsilon$ is energy dissipation and $\sigma$ is surface tension.

\section{Mass transfer coefficient}

Higbie (1935) penetration theory showed that each point of the mass transfer coefficient could be calculated by (Nedeltchev 2003; Dhanasekharan, et al. 2005; Kerdouss, et al. 2008),

$\mathrm{k}_{\mathrm{l}} \mathrm{a}=\sqrt{\frac{4 \mathrm{D}_{\mathrm{i}}}{\pi}}\left(\frac{\varepsilon \rho_{\mathrm{l}}}{\mu_{1}}\right)^{1 / 4} \frac{6 \varphi_{\mathrm{g}}}{\mathrm{d}_{\mathrm{b}}}$

where $\mathrm{D}_{\mathrm{i}}$ is the gas diffusivity in water $\left(\mathrm{i}=\mathrm{O}_{2}, \mathrm{CO}_{2}, \mathrm{~N}_{2}\right)$.

\section{Variation coefficient}

Bohnet and Niesmak (1979) proposed that the variation coefficient could be used to characterize the suspension quality. Barigou and Greaves (1992) extended the application of the variation coefficient to measuring uniformity of the gas dispersion. The uniformity of the mass transfer coefficient could also be measured. The equation for the variation coefficient was as follows:

$\sigma_{\mathrm{x}}=\sqrt{\frac{1}{\mathrm{n}} \sum_{\mathrm{i}=1}^{\mathrm{n}}\left(\frac{\mathrm{x}_{\mathrm{i}}}{\mathrm{x}_{\mathrm{avg}}}-1\right)^{2}}$

where $i$ is represents each finite element, $n$ is the total finite elements, $\mathrm{x}$ is the gas holdup $\left(\varphi_{\mathrm{g}}\right)$ or mass transfer coefficient $\left(\mathrm{k}_{\mathrm{l}} \mathrm{a}\right)$. The larger $\sigma_{\mathrm{x}}$ is, the more non-uniform the distribution of $\mathrm{x}$.

\section{Numerical methodology}

In this manuscript, ANSYS Fluent 17.1 was applied for solving the previous CFD models. All simulation cases were carried out on the model based on the experimental setup, such as stirred bioreactor, impeller and sparger, and then validated with experimental data. The CFD control equation was derived from the threeEuler model, and solved by the finite volume method. The computer domain was divided into two regions of the impeller region (rotating reference frame) and the other region (stationary reference frame), and the MRF approaching method was applied in the computational process. The impeller region was limited in $r / R \leq$ 0.6 and $0.25 \leq \mathrm{z} / \mathrm{T} \leq 0.75$. ICEM was employed for generating tetrahedral elements in the mesh generation process. A good quality of skewness $<0.7$ was ensured and 700,000-900,000 grid elements were provided. SIMPLE was used as a pressure-velocity coupling algorithm and all equations converged with errors under $10^{-4}$. All walls, e.g., reactor wall, impeller blade surface and baffle, were treated as non-slip surfaces and the standard wall function was deployed on them. The reactor top was set as the pressure outlet boundary for the gas phase. The solid concentration was initialized as homogeneous and the region above 
the free surface of the liquid phase was filled with gas. For better discussion, the reactor was divided into three zones: lower zone $\mathrm{z} / \mathrm{T} \leq 0.20$, center zone $0.20 \leq$ $\mathrm{z} / \mathrm{T} \leq 0.45$ and upper zone $\mathrm{z} / \mathrm{T} \geq 0.45$.

\section{RESULTS AND DISCUSSIONS}

\section{Power consumption}

Power number was adapted to measuring power consumption when the impeller speeds were not constant, especially in the gas-liquid-solid three phase stirred bioreactor which was running at the just suspension status. The power numbers could be calculated from the impeller speeds and torques, which were obtained from the conditions $\left(\mathrm{Q}_{\mathrm{g}}=4,8,12 \mathrm{~L} / \mathrm{min}\right.$, $\mathrm{X}=5,10,15,20 \mathrm{wt} \%$ ) under the just suspension status. The torques of the experiment and simulation could be calculated by eq.(16) and eq.(3), respectively. The power numbers of the experiment and simulation were both plotted in Fig.2.
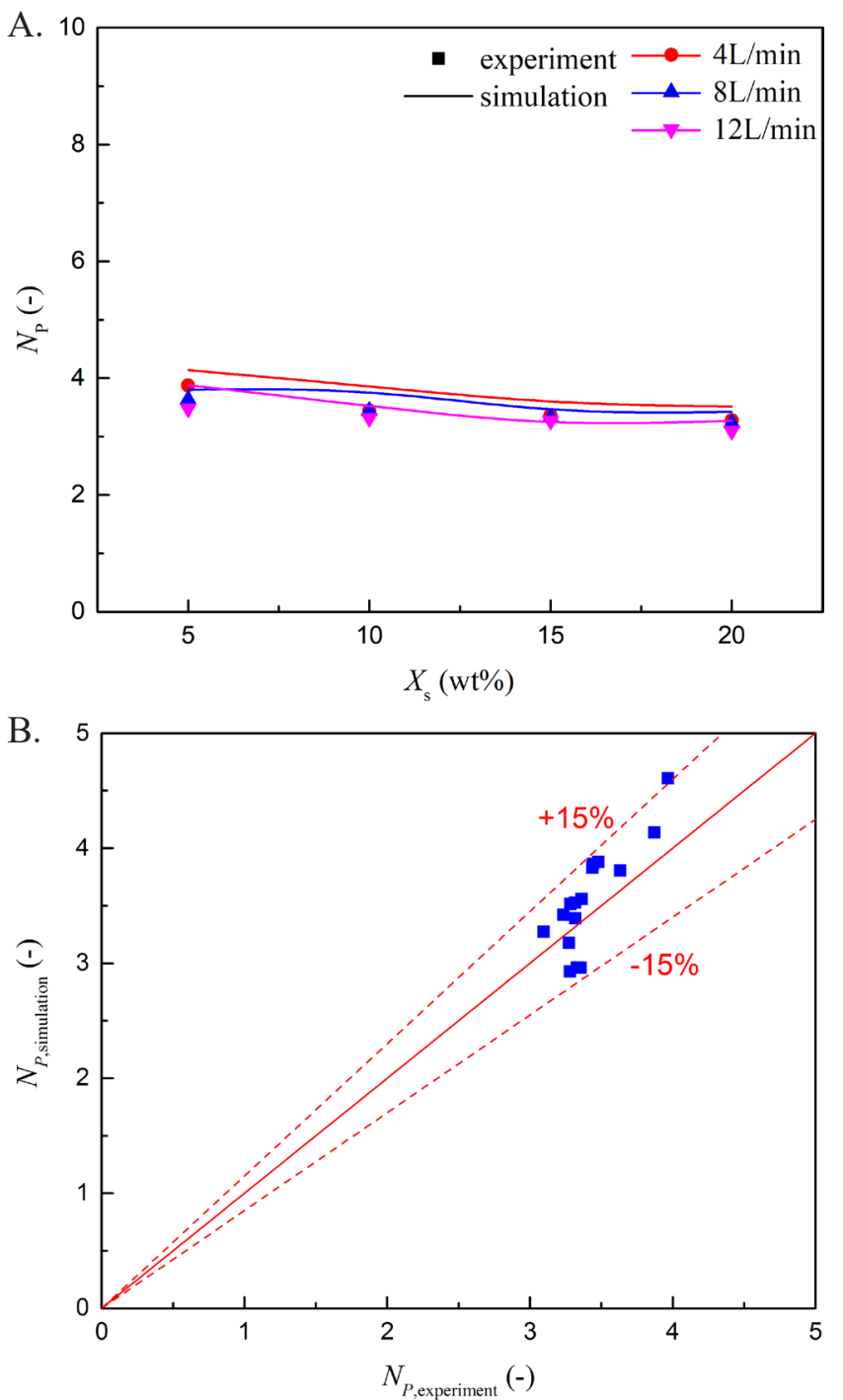

Figure 2. Comparison of simulation and experimental results of power number
As Fig.2(a) shows, the simulation results agreed with the experiment and, as Fig.2(b) shows, the errors between them were less than $15 \%$. Hence, the power consumption could be well simulated in the gas-liquidsolid three-phase stirred bioreactor. The power number was not significantly changed by the aeration rate and solid concentration under the just suspension status.

The turbulent energy dissipation, which was the characteristic parameter of the local power consumption, was apparently different along with the axial direction (as shown in Fig. 3), especially in the aeration system. To validate the local power consumption of the CFD simulation, the experimental data, which were obtained from PIV technology by Geng, et al. (2012), were considered in the comparison (as shown in Fig.4).

As Fig.4 shows, the conditions, e.g. the lower, center and upper regions, and the aeration rates, were

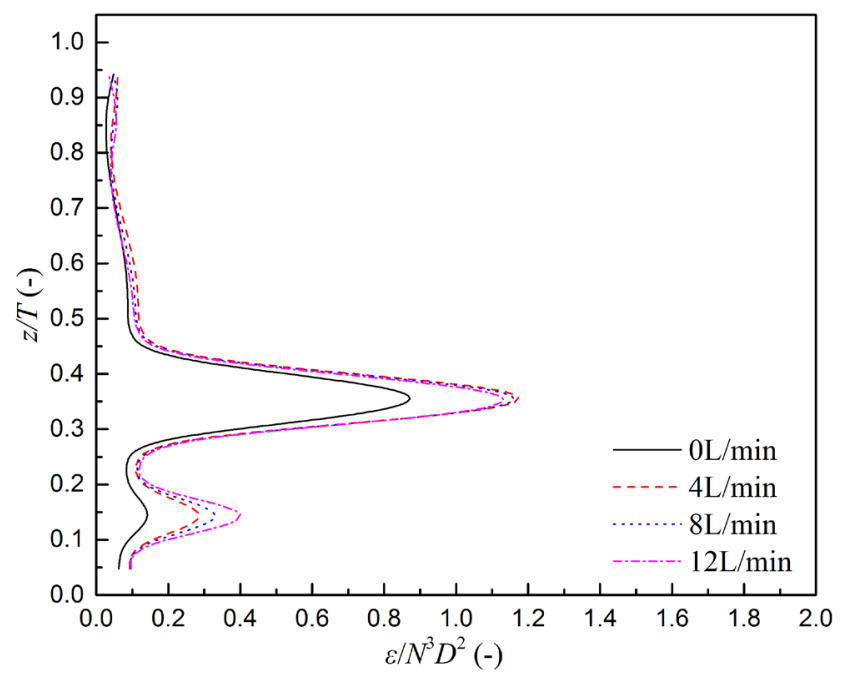

Figure 3. The axial distribution of the dimensionless turbulent energy dissipation rate.

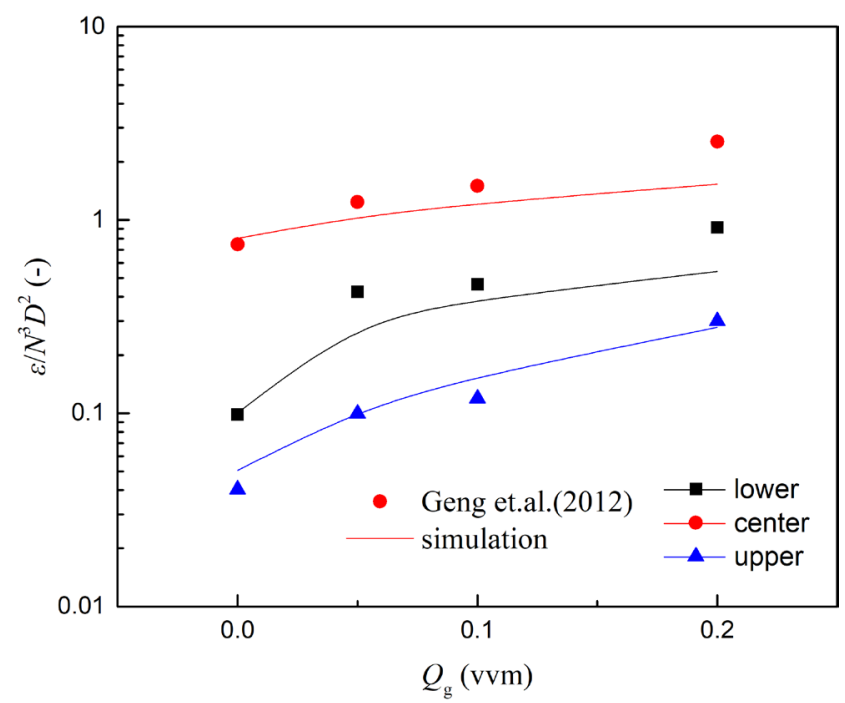

Figure 4. Comparison of results for the dimensionless turblunent energy dissipation rate. 
all consistent with the literature (Geng, et al. 2012). The results showed that the simulation data were in agreement with experiment. The center zone consumed a great deal of energy.

\section{Gas holdup}

Under the condition of $\mathrm{Q}_{\mathrm{g}}=12 \mathrm{~L} / \mathrm{min}, \mathrm{X}_{\mathrm{s}}=5$ $\mathrm{wt} \%$, the just suspension speed was $394 \mathrm{rpm}$; the experimental data of the gas holdup were measured with a conductivity probe. Then the simulation data were compared with them, as shown in Fig.5.

Fig.5(a) was created for the data limits and interpolation method. Compared with the simulation result (Fig.5(b)), the cloud show the same trends. To analyze the difference between the experimental and simulation data, the data at the position of $\mathrm{z} /$ $\mathrm{T}=0.60,0.75$ and $\mathrm{r} / \mathrm{R}=0.56,0.73,0.82$ were extracted to make a comparison, shown in Fig.6. As Fig.6 shows,

(a) Experiment

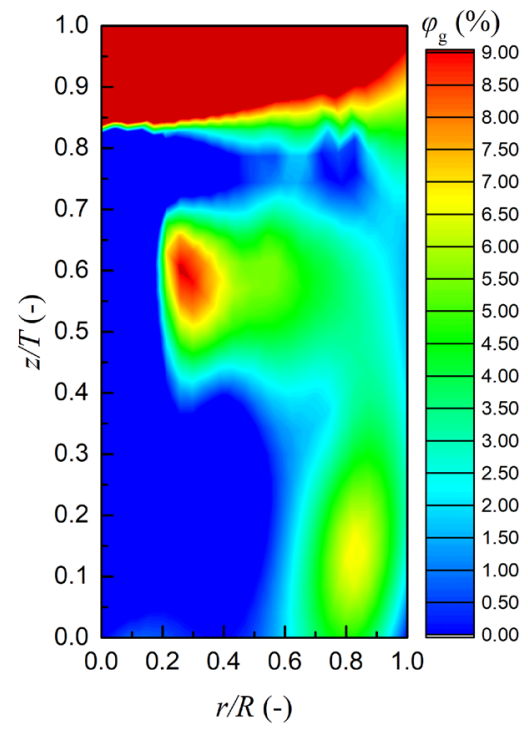

(b) Simulation

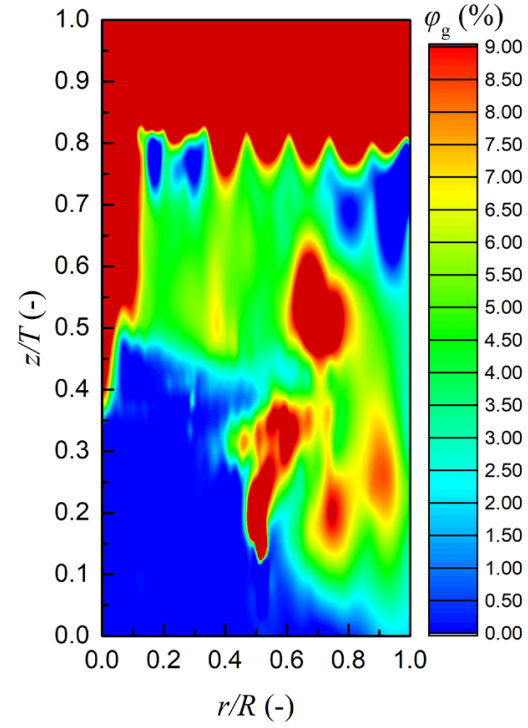

Figure 5. The spatial distribution of the gas holdup. (a) Gas holdup via radial direction

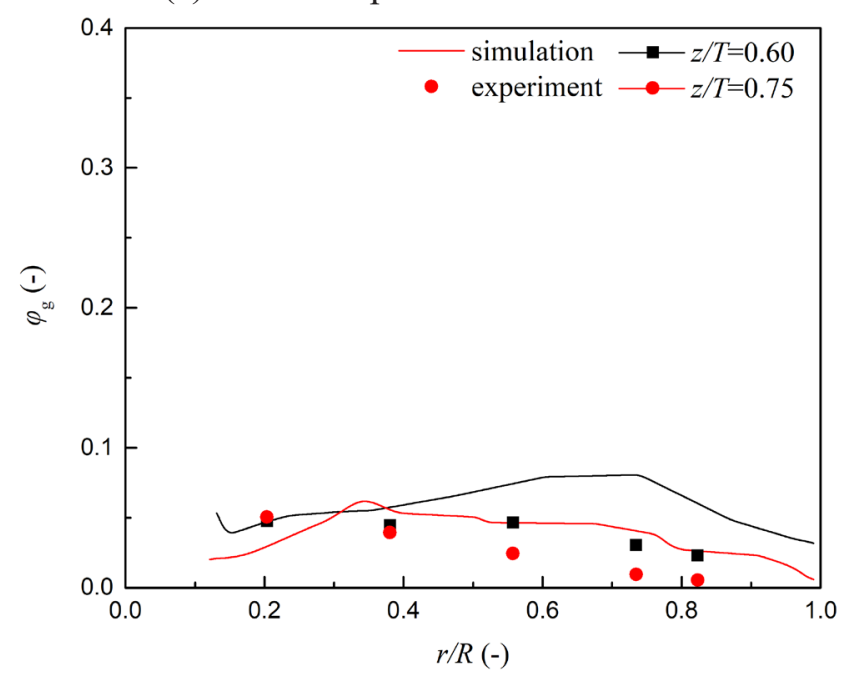

(b) Gas holdup via axial position

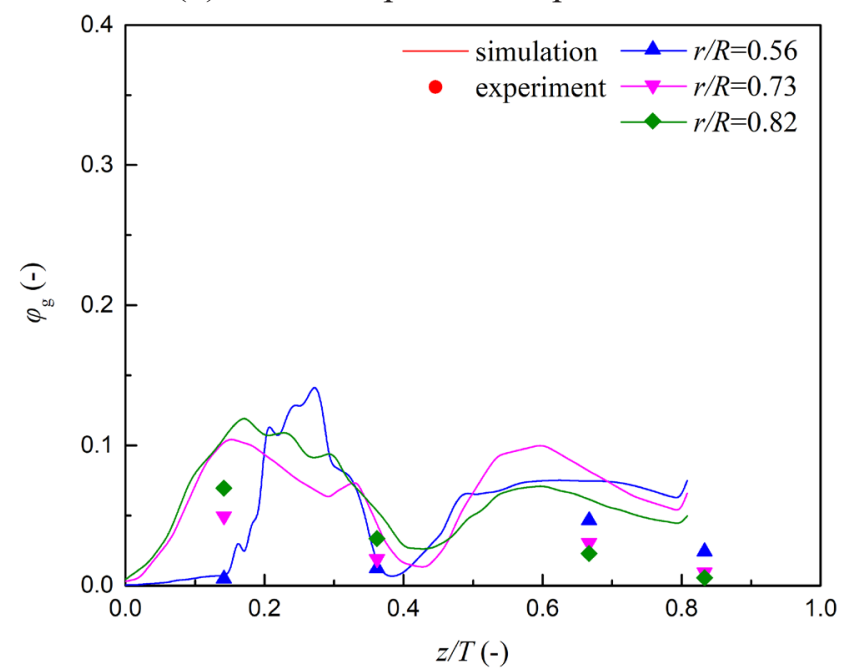

Figure 6. Comparison of simulation and experimental results of local gas holdup.

the experimental and simulation local gas holdup followed the same trend.

As Fig. 5 shows, the spatial distributions of the gas holdup were very different. To investigate this difference, the reactor was divided into three zones of lower, center and upper. The gas holdup of each zone varied with the aeration rate and solid concentration under the just suspension status. The trends of these variations are shown in Fig.7.

As Fig.7 shows, the gas holdup in all zones was mainly affected by the aeration rate and little impacted by the solid concentration under the just suspension status. In each zone, the gas holdup also changed clearly. Therefore, to measure these changes, the variation coefficient of the gas holdup was taken into account in this work. The trend of the variation coefficients via the aeration rate and solid concentration are demonstrated in Fig.8. According to Fig.7 and Fig.8, the gas holdup in the lower zone was very unevenly distributed. Thus the lower impeller clearance was important. 

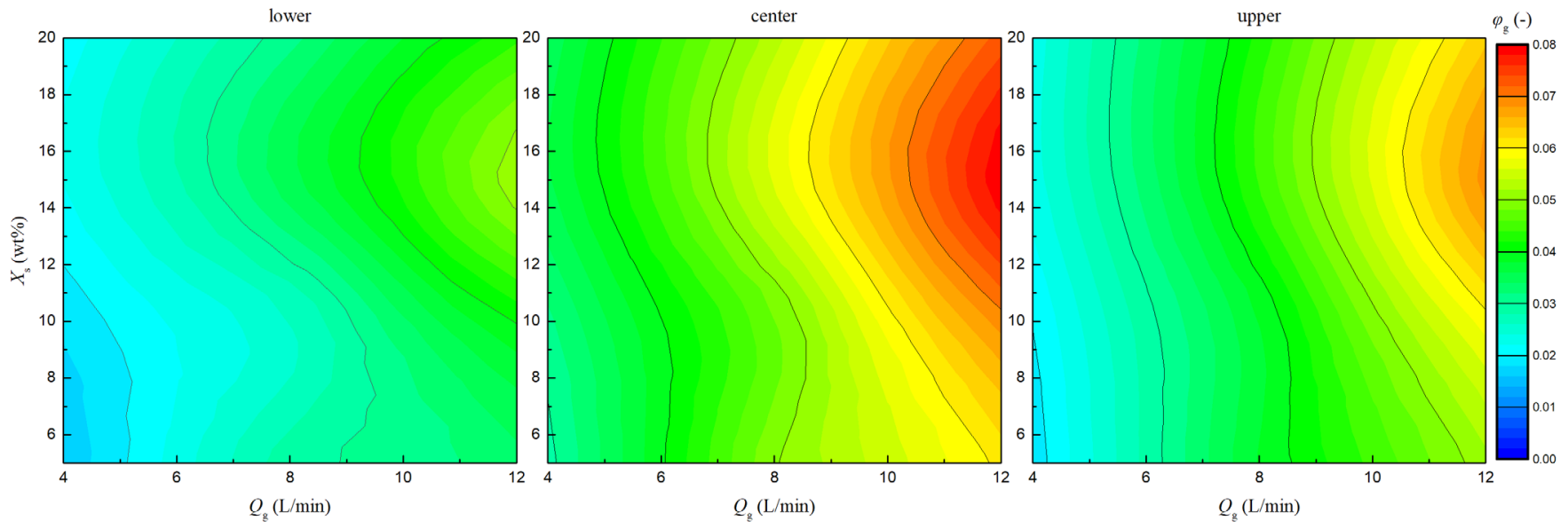

Figure 7. Trend map of the gas holdup for different zones.
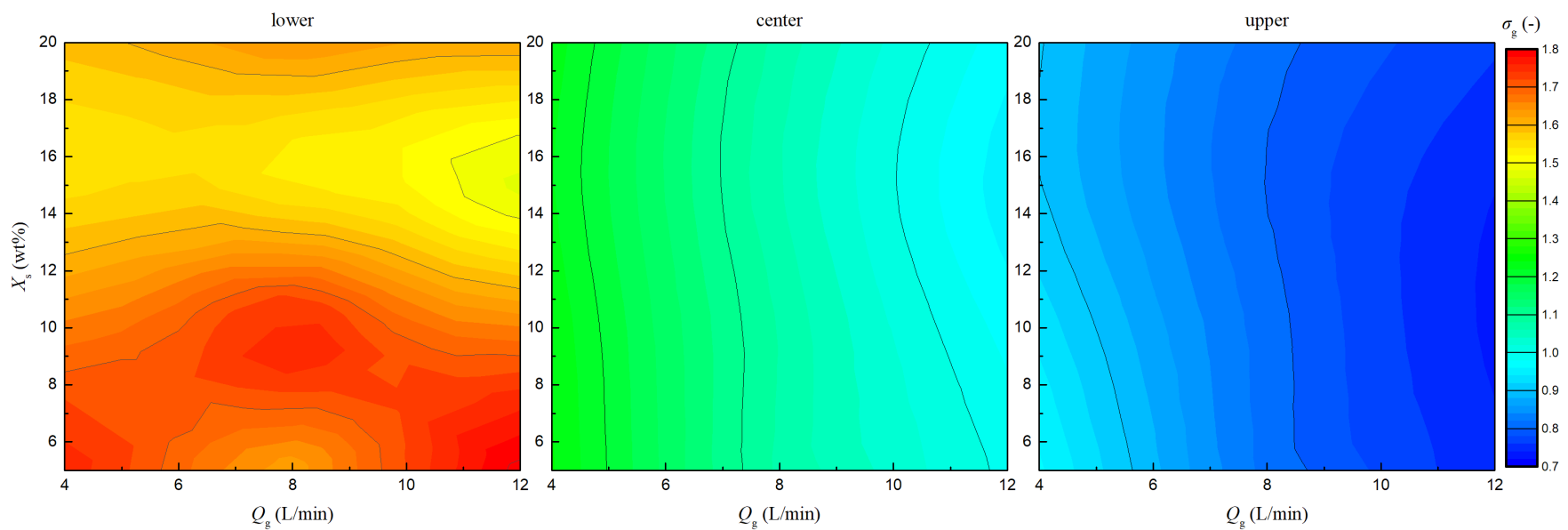

Figure 8. Trend map of the variation of the gas holdup for different zones.

\section{Bubble diameter}

Under the condition of $\mathrm{Q}_{\mathrm{g}}=12 \mathrm{~L} / \mathrm{min}, \mathrm{X}_{\mathrm{s}}=5 \mathrm{wt} \%$, $\mathrm{N}_{\mathrm{js}}=394 \mathrm{rpm}$, the experimental data of the bubble diameter were measured with a conductivity probe.
There were two different models for calculating the bubble diameter (Yang, et al. 2016; Zheng, et al. 2018), and the simulation data were compared with them, as shown in Fig.9. (a) Experiment

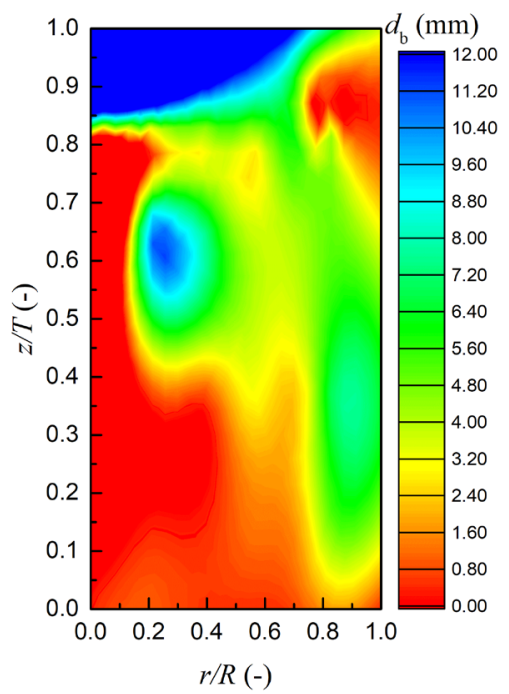

(b) Simulated by Yang, et al. (2016)

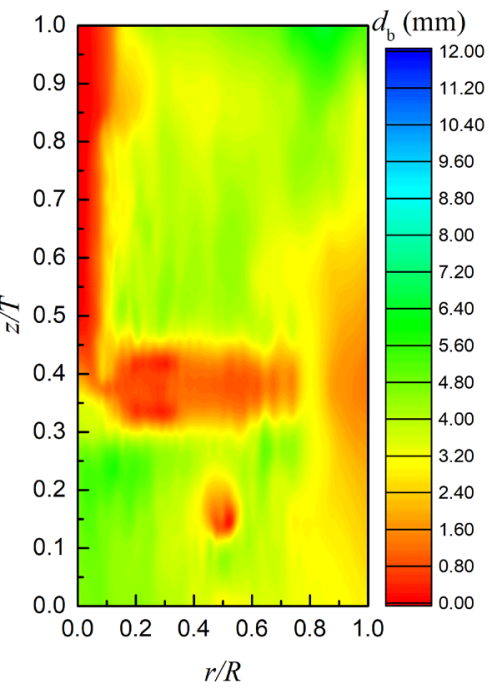

(c) Simulated by Davoody, et al. (2016)

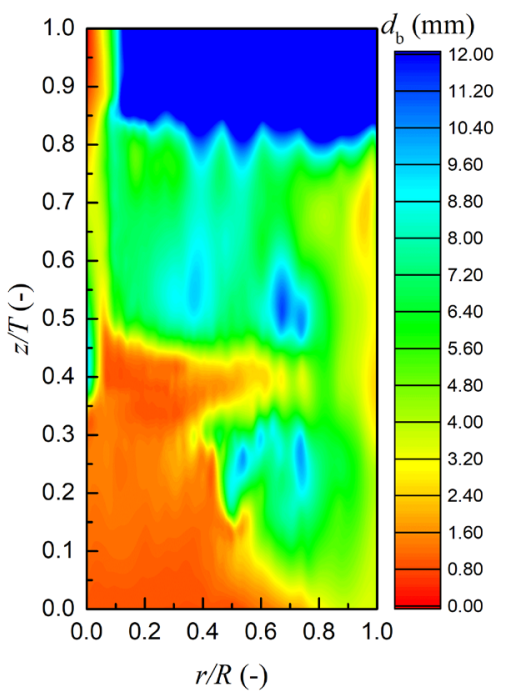

Figure 9. The spatial distribution of the bubble diameter. 
Fig.9(a) was created for the data limits and interpolation method. Compared with the simulation result (Fig.9(b)-(c)), the cloud maps of Fig.9(a) and (c) showed the same trends, and Fig.9(b) showed different trends. It appeared that the Davoody et al. (2016) model could be more applicable than the Yang et al. (2016) model. To confirm the most feasible model, the Sauter mean bubble diameters in the experimental and simulation in all conditions $\left(\mathrm{Q}_{\mathrm{g}}=4,8,12 \mathrm{~L} / \mathrm{min}, \mathrm{X}_{\mathrm{s}}=\right.$ $5,10,15,20 \mathrm{wt} \%$ ) were simulated by the two different models and plotted together, as shown in Fig. 10.

As Fig. 10(a) shows, the simulation data were all in agreement with the trends, but the simulation data given by the Yang et al. (2016) model were significantly greater than the experimental data. According to Fig. 10(b), the Yang et al. (2016) model should be revised by the correction coefficient 0.8. As Fig. 10(b) shows, the simulation results of both the revised Yang et al. (2016) model and the Davoody et al. (2016) model agreed with
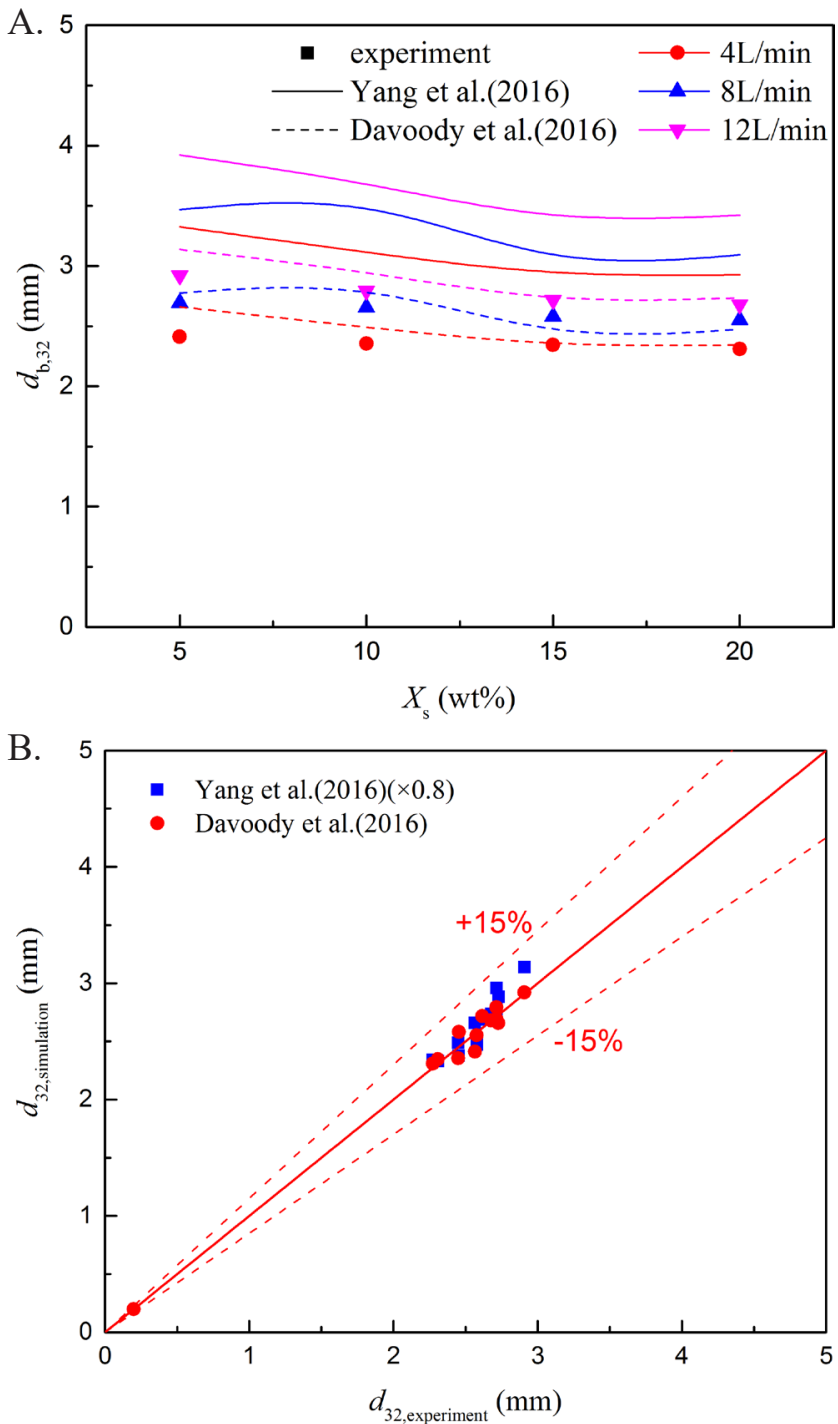

Figure 10. Comparison of simulation and experimental results of Sauter mean bubble diameter. experiment. In conclusion, the Davoody et al. (2016) model should be recommended in this work.

\section{Mass transfer coefficient}

There are a lot of studies of the mass transfer coefficient based on theoretical and empirical considerations (Chisti and Jauregui-Haza, 2002; Martín et al. 2008). The mass transfer coefficient could be accurately estimated. Eq.(4) suggested by Chandrasekharan and Calderbank (1981) was used to calculate the mass transfer coefficient from the aeration rate and the power comsumption. The estimation and simulation data on all conditions $\left(\mathrm{Q}_{\mathrm{g}}=4,8,12 \mathrm{~L} / \mathrm{min}\right.$, $\mathrm{X}_{\mathrm{s}}=5,10,15,20 \mathrm{wt} \%$ ) were plotted in Fig. 11 .

As Fig.11(a) shows, the simulation results agreed with experiment, and as Fig.11(b) shows, the errors between them are less than $30 \%$. Hence, the simulation data could be applied for further analysis. The spatial distribution of the mass transfer coefficients, obtained under the condition of $\mathrm{Q}_{\mathrm{g}}=12 \mathrm{~L} / \mathrm{min}, \mathrm{X}_{\mathrm{s}}=5 \mathrm{wt} \%, \mathrm{~N}_{\mathrm{js}}$ $=394 \mathrm{rpm}$, is displayed in Fig. 12 .
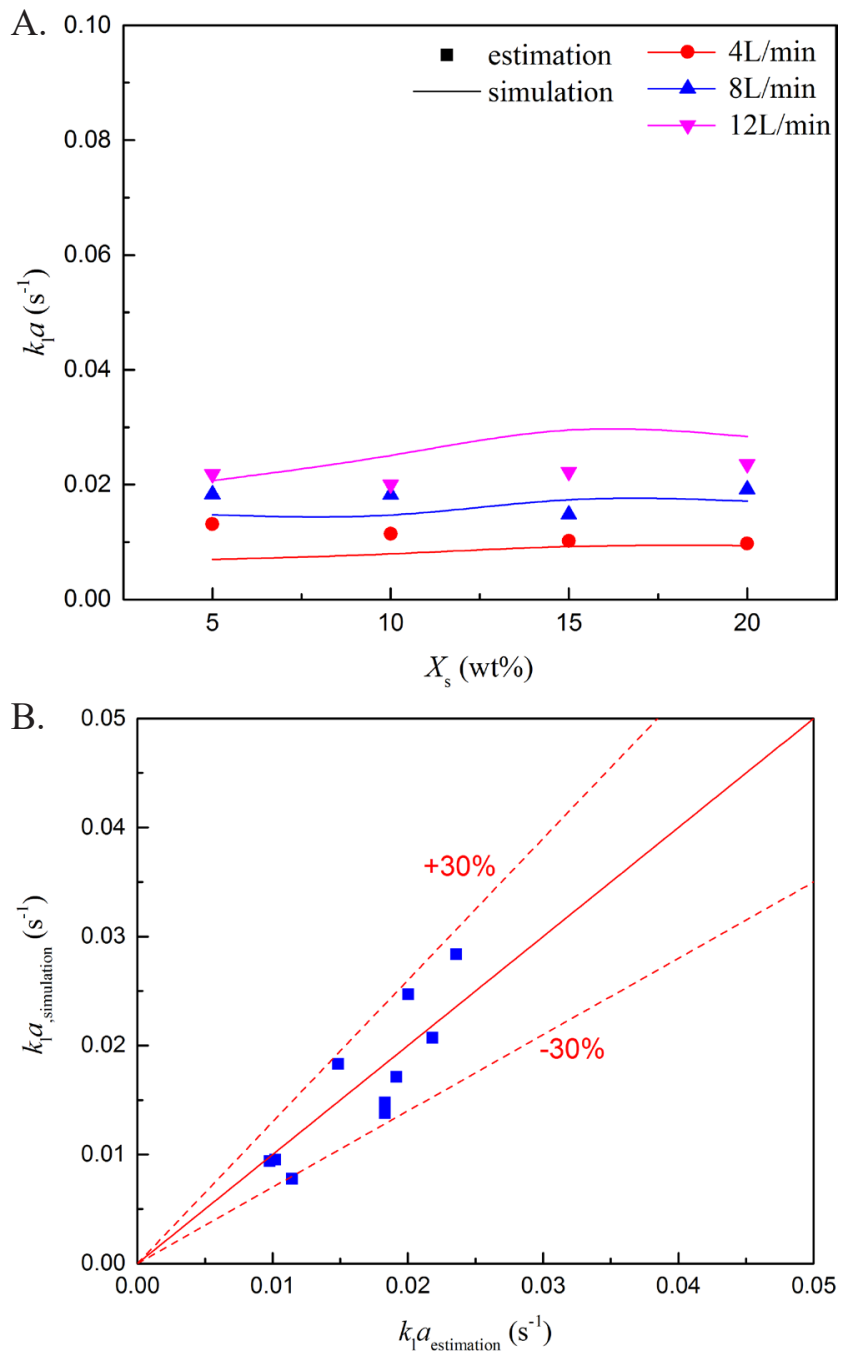

Figure 11. Comparison of estimation and experimental results of the mass transfer coefficient. 
(a) Vertical

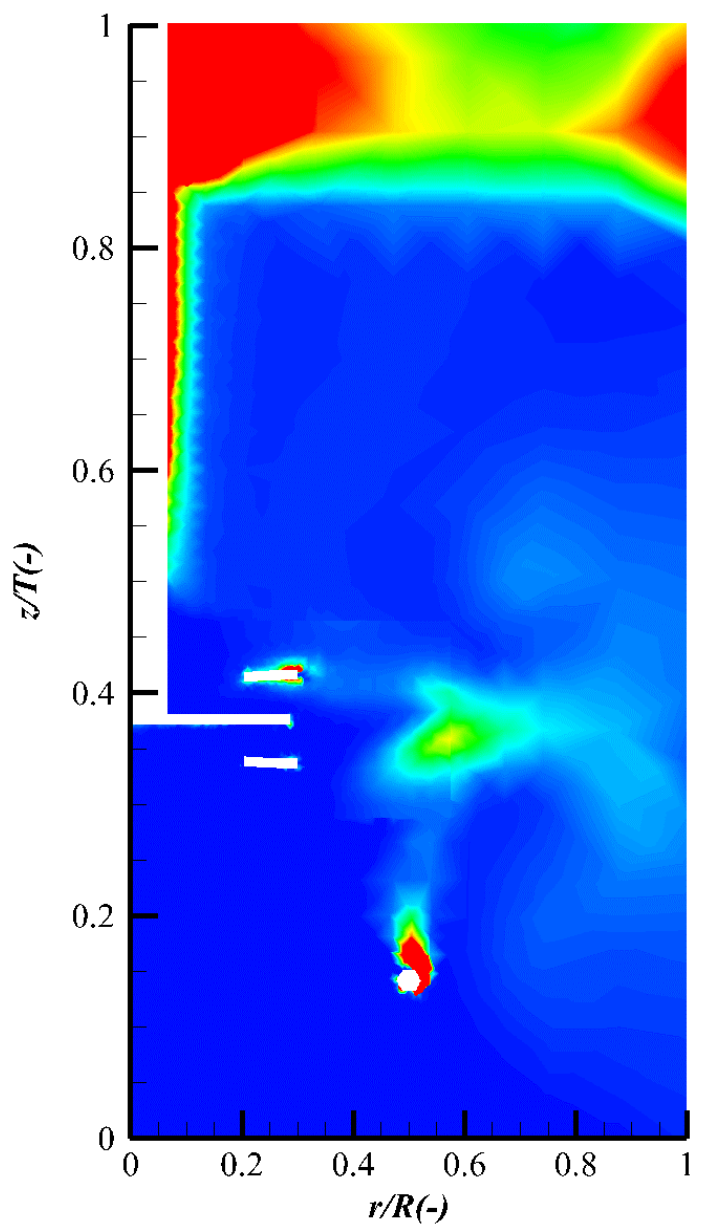

(b) Middle

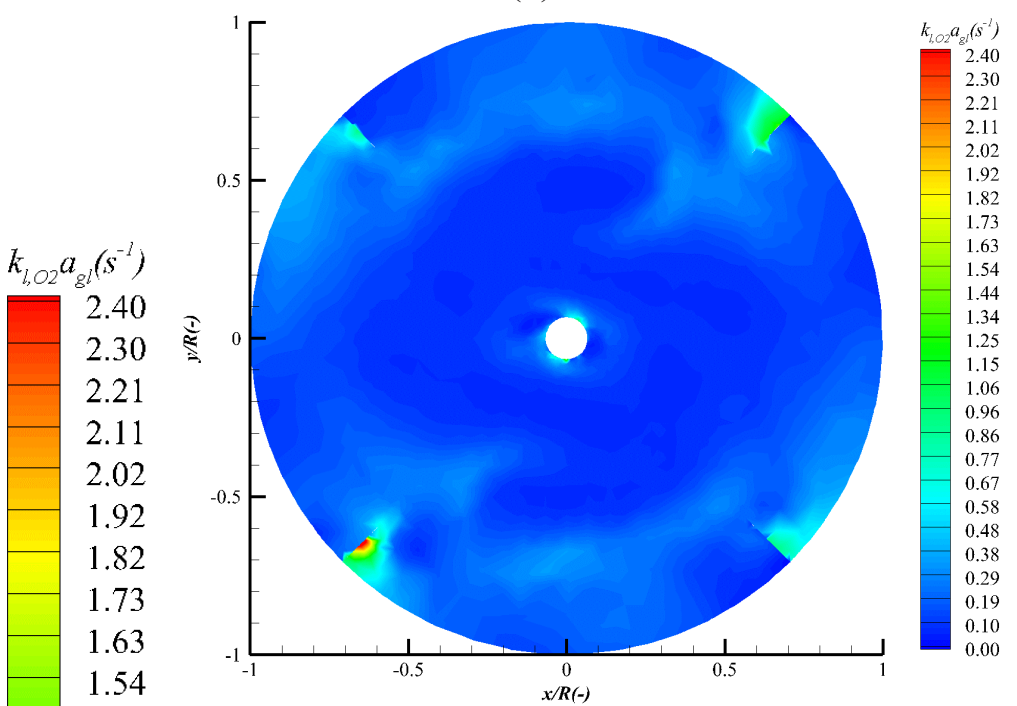

(c) Impeller

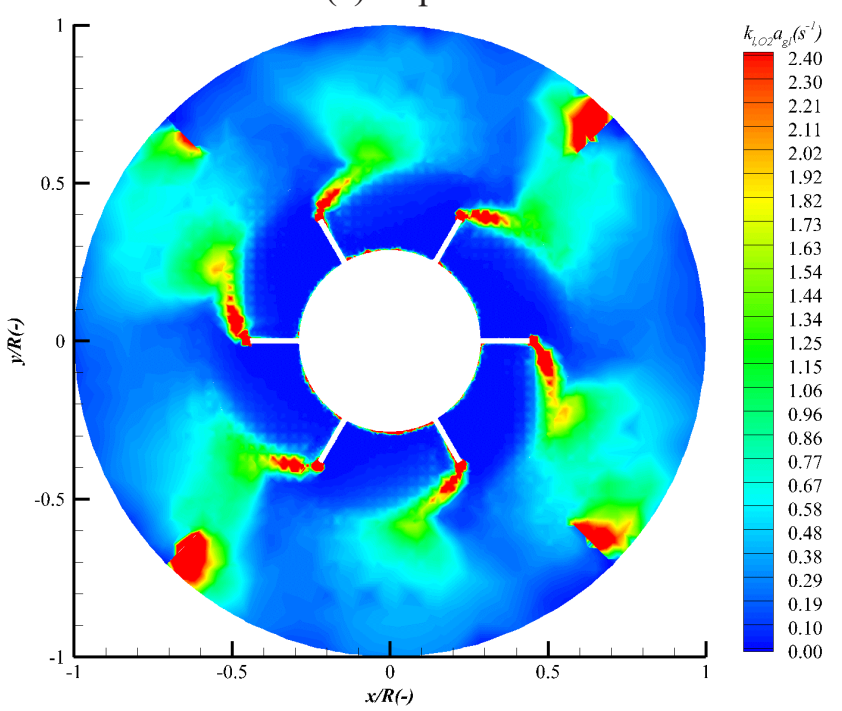

Figure 12. The spatial distribution of the mass transfer coefficient.

As Fig.12(a) and (c) show, the maximum values of the mass transfer coefficient were at the impeller tip and sparger, while the minimum values were under the impeller. As Fig.12(a) and (b) show, compared with the zones on and under the impeller, the mass transfer coefficients over the impeller zone were more
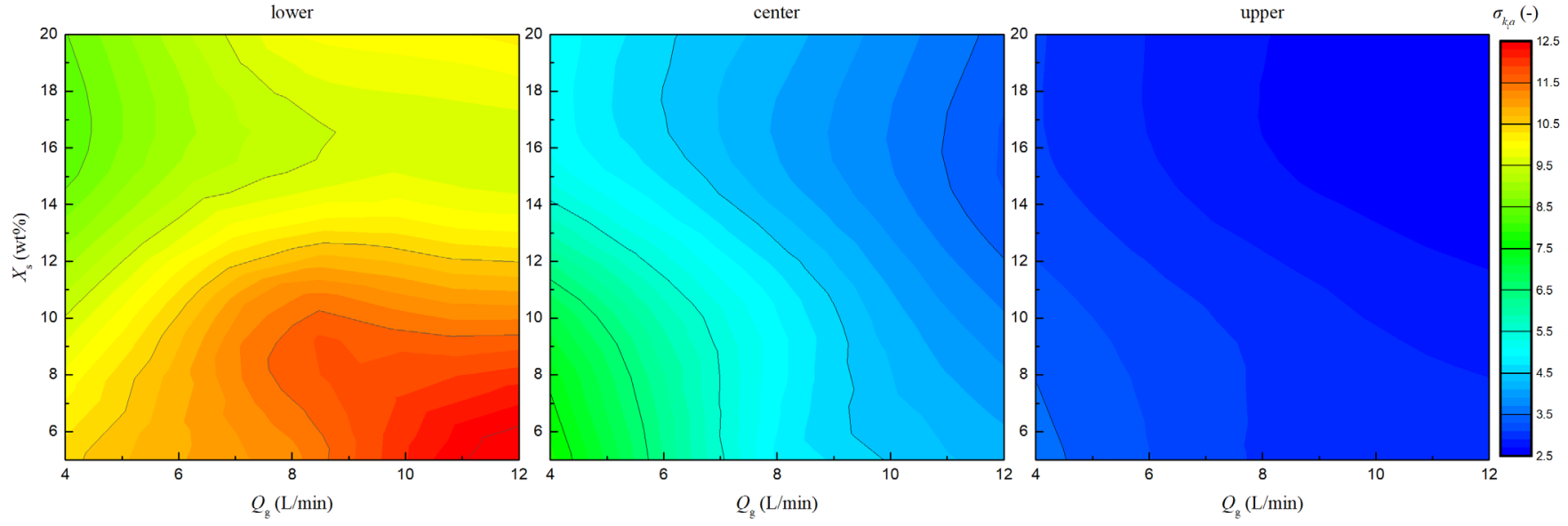

Figure 13. Trend map of the variation of the mass transfer coefficient for different zones. 
well-distributed. To prove this point, the variation coefficient of the mass transfer coefficients via the aeration rate and solid concentration in three separated zones are plotted in Fig. 13.

As Fig.13 shows, the higher aeration rate could more easily bring about an uneven distribution of the mass transfer coefficient in the lower zone (under the impeller zone). The variation coefficient of the mass transfer coefficient could significantly change in the center zone (the impeller zone), and the distribution of the mass transfer coefficient was slightly changed with the aeration rate or solid concentration in the upper zone (over the impeller zone). Well-distributed in the upper zone, a higher solid concentration could improve the uniform distribution of the mass transfer coefficient over the reactor.

\section{CONCLUSIONS}

In this work, an Eulerian multi-fluid model and the standard $\mathrm{k}-\varepsilon$ turbulence model were developed for simulating the gas-liquid-solid three-phase stirred bioreactor. The power consumption, bubble diameter and mass transfer coefficient models were applied for further analysis. The simulation results of the power consumption, gas holdup, bubble diameter and mass transfer coefficient were all validated by the experimental or estimation data, respectively. All cases were studied for the just suspension status. The main conclusions can be listed as follows,

(1) Good agreement was found between the simulated and measured/estimated variables, such as the power consumption, gas holdup, bubble diameter and mass transfer coefficient, in the gas-liquid-solid three-phase stirred bioreactor. The errors of the power consumption and bubble diameter were both less than $15 \%$, and the errors of the mass transfer coefficient were less than $30 \%$.

(2) The power number did not significantly change with the aeration rate and solid concentration under the just suspension status. The turbulent energy dissipation, which was the characteristic parameter of the local power consumption, was apparently different along the axial direction and the center zone consumes a great deal of energy.

(3) The gas holdup of each zone was mainly affected by the aeration rate and little impacted by the solid concentration under the just suspension status. The variation coefficient of the gas holdup showed that the gas holdup was very unevenly distributed in the lower zone, and the lower impeller clearance was important.

(4) Even though the Yang model was revised by the correction coefficient 0.8 , the spatial trend did not agree with the experimental cloud map. The Davoody model could be more applicable and is strongly recommended for simulating the bubble diameter in further studies.

(5) The higher aeration rate could more easily bring about an uneven distribution of the mass transfer coefficient in the lower zone (under the impeller zone). The variation coefficient of the mass transfer coefficient significantly changed in the center zone (the impeller zone), and the distribution of the mass transfer coefficient was slightly changed with the aeration rate or solid concentration in the upper zone (over the impeller zone). Well-distributed at the upper zone, a higher solid concentration could improve the uniform distribution of the mass transfer coefficient over the reactor.

\section{NOMENCLATURE}

\begin{tabular}{|c|c|}
\hline A & Area $\left(\mathrm{m}^{2}\right)$ \\
\hline $\mathrm{C}$ & $\begin{array}{l}\text { The distance of the impeller from the reactor } \\
\text { (tank, also called vessel) bottom, also called } \\
\text { impeller clearance (m) }\end{array}$ \\
\hline $\mathrm{C}_{\mathrm{C}}$ & Drag force constant $(\mathrm{m})$ \\
\hline $\mathrm{D}^{\mathrm{D}}$ & Impeller diameter $(\mathrm{m})$ \\
\hline $\mathrm{D}_{\mathrm{i}}$ & The diffusion coefficient of $i$ component $\left(\mathrm{m}^{2} / \mathrm{s}\right)$ \\
\hline$d_{b}^{1}$ & The gas bubble diameter $(\mathrm{m})$ \\
\hline$d_{p}^{0}$ & The solid particle size (m) \\
\hline $\mathrm{d}_{\mathrm{s}}^{\mathrm{p}}$ & $\begin{array}{l}\text { The distance of two points separated by } \\
\text { bubble, particle, eddy or bacteria (m) }\end{array}$ \\
\hline $\mathrm{F}$ & Force per unit volume $\left(\mathrm{N} / \mathrm{m}^{3}\right)$ \\
\hline $\mathrm{g}$ & Acceleration of gravity $\left(\mathrm{m} / \mathrm{s}^{2}\right)$ \\
\hline $\mathrm{H}$ & Height of reactor $(\mathrm{m})$ \\
\hline $\mathrm{H}_{1}$ & Liquid free surface off-bottom (m) \\
\hline $\mathrm{h}$ & $\begin{array}{l}\text { The ring sparger clearance, the height from } \\
\text { the center of the flat bottom }(\mathrm{m})\end{array}$ \\
\hline K & An empirical constant \\
\hline $\mathrm{k}$ & Turbulent kinetic energy $\left(\mathrm{J} / \mathrm{m}^{3}\right)$ \\
\hline $\mathrm{N}$ & Impeller speed (rps) \\
\hline $\mathrm{N}_{\mathrm{p}}$ & Power number (-) \\
\hline $\mathrm{p}$ & Pressure of flow $(\mathrm{Pa})$ \\
\hline $\mathrm{P}$ & Power demand of the agitation (W) \\
\hline$Q_{g}$ & Aeration rate $(\mathrm{L} / \mathrm{h})$ \\
\hline$Q_{m}$ & Aeration rate $\left(\mathrm{m}^{3} / \mathrm{s}\right)$ \\
\hline r & Radius (m) \\
\hline $\operatorname{Re}$ & Reynolds number \\
\hline $\mathrm{T}$ & Reactor (vessel) diameter (m) \\
\hline $\mathrm{T}_{\mathrm{a}}$ & The torque of agitation $(\mathrm{N} . \mathrm{m})$ \\
\hline $\mathrm{t}$ & Time $(s)$ \\
\hline $\mathrm{u}_{\mathrm{i}}$ & Reynolds average velocity of the phase $\mathrm{i}(\mathrm{m} / \mathrm{s})$ \\
\hline $\mathrm{u}_{\mathrm{d}_{\mathrm{s}}}$ & $\begin{array}{l}\text { The velocity fluctuations at two points } \\
\text { separated by } d_{s}(\mathrm{~m} / \mathrm{s})\end{array}$ \\
\hline $\mathrm{u}_{\mathrm{d}_{\mathrm{b}}}$ & $\begin{array}{l}\text { Fluctuation velocity of turbulent flow at } \\
\text { bubble scale }(\mathrm{m} / \mathrm{s})\end{array}$ \\
\hline $\mathrm{V}$ & Entire liquid volume $\left(\mathrm{m}^{3}\right)$ \\
\hline $\mathrm{X}_{\mathrm{s}}$ & $\begin{array}{l}\text { Solid concentration, also called solid mass } \\
\text { fraction or, solid loading ( } \% \mathrm{wt})\end{array}$ \\
\hline
\end{tabular}




\section{Greek symbols}

$\delta_{\varepsilon} \quad$ Turbulent Prandtl number for the dissipation rate

$\delta_{\mathrm{k}} \quad$ Turbulent Prandtl number for the turbulent kinetic energy

$\varepsilon \quad$ Turbulence energy dissipation rate $\left(\mathrm{m}^{2} / \mathrm{s}^{2}\right)$

$\lambda \quad$ Kolmogorov length scale $(\mathrm{m})$

$\mu \quad$ Viscosity (Pa.s)

$v \quad$ Kinematic viscosity $\left(\mathrm{m}^{2} / \mathrm{s}\right)$

$\tau \quad$ Shear stress $(\mathrm{Pa})$

$\rho \quad$ Density $\left(\mathrm{kg} / \mathrm{m}^{3}\right)$

$\sigma_{1} \quad$ Surface tension of liquid $(\mathrm{N} / \mathrm{m})$

$\sigma_{\mathrm{s}} \quad$ The variation coefficient (normalized standard deviation) for solid

$\varphi_{i} \quad$ Volume fraction of i phase

$\omega \quad$ Angular velocity ( $\mathrm{rad} / \mathrm{s})$

\section{Subscripts \\ b Bubble \\ D Drag}

avg Average value

g Gas or gassed conditions

js Just suspended condition for solids

1 Liquid

$\lg \quad$ Action between liquid and gas

ls Action between liquid and solid

m Max

$\mathrm{p} \quad$ Particle

s Solid

t Turbulent

v Viscosity

\section{Abbreviations \\ CFD Computational fluid dynamics \\ HEDT Half elliptical blades disk turbine \\ PIV Particle image velocimetry}

\section{ACKNOWLEDGMENT}

We acknowledge the financial support of the Science and Technology Department of Fujian Province, China, and the National Natural Science Foundation of China and Fujian (NO.2014R1004-3, NO.21476049, NO.21506033, NO.2015J01052, 2016 H4023 and FG-2016005). We thank Fuzhou University for CFD simulation support and Xiamen Zijin Mining \& Metallurgy Technology Co., Ltd. for equipment and instrument support.

\section{REFERENCES}

Akbari, V., Nejad Ghaffar Borhani, T., Shamiri, A., Kamaruddin Abd, M. Hamid. A CFD-PBM coupled model of hydrodynamics and mixing/segregation in an industrial gas-phase polymerization reactor. Chemical Engineering Research and Design,
96, 103-120 (2015). https://doi.org/10.1016/j. cherd.2015.02.007

Atef, N. M., Abdel-Aziz, M. H., Fouad, Y. O., Farag, H. A., Sedahmed, G. H., Mass and heat transfer at an array of horizontal cylinders placed at the bottom of a square agitated vessel. Chemical Engineering Research and Design, 94, 449-455 (2015). https:// doi.org/10.1016/j.cherd.2014.09.001

Bakker, A., Vandenakker, H. A Computational Model For The Gas-Liquid Flow In Stirred Reactors. Chemical Engineering Research and Design, 72, 594-606 (1994).

Barigou, M., Greaves, M. Bubble-size distributions in a mechanically agitated gas-liquid contactor. Chemical Engineering Science, 47, 20092025 (1992). https://doi.org/10.1016/00092509(92)80318-7

Barrue, H., Bertrand, J. O., Euml, B., Icirc, C., Xuereb, C. Eulerian Simulation of Dense Solid-Liquid Suspension in Multi-Stage Stirred Vessel. Journal of Chemical Engineering of Japan, 34, 585-594 (2001). https://doi.org/10.1252/jcej.34.585

Bohnet, M., Niesmak, G. Distribution of solids in stirred suspension. German Chemical Engineering, 51, 314-315 (1979). https://doi.org/10.1002/ cite. 330510415

Boon, M., Heijnen, J. J. Chemical oxidation kinetics of pyrite in bioleaching processes. Hydrometallurgy, 48, 27-41 (1998). https://doi.org/10.1016/S0304386X(97)00072-8

Bouillard, J. X., Lyczkowski, R. W., Gidaspow, D. Porosity distributions in a fluidized bed with an immersed obstacle. AIChE Journal, 35, 908-922 (1989). https://doi.org/10.1002/aic.690350604

Brucato, A., Grisafi, F., Montante, G. Particle drag coefficients in turbulent fluids. Chemical Engineering Science, 53, 3295-3314 (1998). https://doi.org/10.1016/S0009-2509(98)00114-6

Buffo, A., Vanni, M., Marchisio, D. L. Simulation of a reacting gas-liquid bubbly flow with CFD and PBM: Validation with experiments. Applied Mathematical Modelling, 44, 43-60 (2017). https:// doi.org/10.1016/j.apm.2016.11.010

Buffo, M. M., Corrêa, L. J., Esperança, M. N., Cruz, A. J. G., Farinas, C. S., Badino, A. C. Influence of dualimpeller type and configuration on oxygen transfer, power consumption, and shear rate in a stirred tank bioreactor. Biochemical Engineering Journal, 114, 130-139 (2016). https://doi.org/10.1016/j. bej.2016.07.003

Calderbank, P. H. Physical rate processes in industrial fermentation. Part I: the interfacial area in gas-liquid contacting with mechanical agitation. Transactions of the Institution of Chemical Engineers, 36, 443463 (1958). 
Chandrasekharan, K., Calderbank, P. H. Further observations on the scale-up of aerated mixing vessels. Chemical Engineering Science, 36, 818-823 (1981). https://doi.org/10.1016/00092509(81)85033-6

Chisti, M. Y., Moo-Young, M. Hydrodynamics and oxygen transfer in pneumatic bioreactor devices. Biotechnology and Bioengineering, 31, 487-494 (1988). https://doi.org/10.1002/bit.260310514

Chisti, Y., Jauregui-Haza, U. J. Oxygen transfer and mixing in mechanically agitated airlift bioreactors. Biochemical Engineering Journal, 10, 143-153 (2002). https://doi.org/10.1016/S1369703X(01)00174-7

Davoody, M., Abdul Raman, A. A. B., Parthasarathy, R. Maximizing gas-liquid interfacial area in a three-phase stirred vessel operating at high solids concentrations. Chemical Engineering and Processing: Process Intensification, 104, 133-147 (2016). https://doi.org/10.1016/j.cep.2016.02.007

Dhanasekharan, K. M., Sanyal, J., Jain, A., Haidari, A. A generalized approach to model oxygen transfer in bioreactors using population balances and computational fluid dynamics. Chemical Engineering Science, 60, 213-218 (2005). https:// doi.org/10.1016/j.ces.2004.07.118

Ding, J., Wang, X., Zhou, X.-F., Ren, N.-Q., Guo, W.-Q. CFD optimization of continuous stirredtank (CSTR) reactor for biohydrogen production. Bioresource Technology, 101, $7005-7013$ (2010). https://doi.org/10.1016/j.biortech.2010.03.146

Elghobashi, S. E., Abou-Aab, T. W. A two - equation turbulence model for two - phase flows. The Physics of Fluids, 26, 931-938 (1983). https://doi. org/10.1063/1.864243

Geng, X., Gao, Z., Bao, Y. PIV Study of Flow in an Aerated Tank with a Hollow Blade Turbine. International Journal of Chemical Reactor Engineering, 10, A17 (2012). https://doi. org/10.1515/1542-6580.2889

Gentric, C., Mignon, D., Bousquet, J., Tanguy, P. A. Comparison of mixing in two industrial gasliquid reactors using CFD simulations. Chemical Engineering Science, 60, 2253-2272 (2005). https://doi.org/10.1016/j.ces.2004.11.045

Guo, K., Wang, T., Liu, Y., Wang, J. CFD-PBM simulations of a bubble column with different liquid properties. Chemical Engineering Journal, 329, 116-127 (2017). https://doi.org/10.1016/j. cej.2017.04.071

Hansford, G. S., Vargas, T. Chemical and electrochemical basis of bioleaching processes. Hydrometallurgy, 59, 135-145 (2001). https://doi. org/10.1016/S0304-386X(00)00166-3

Herrera, M. N., Wiertz, J. V., Ruiz, P., Neuburg, H. J., Badilla-Ohlbaum, R. A phenomenological model of the bioleaching of complex sulfide ores. Hydrometallurgy, 22, 193-206 (1989). https://doi. org/10.1016/0304-386X(89)90050-9

Higbie, R. The Rate of Absorption of A Pure Gas into A Still Liquid During Short Period of Exposure. Trans. AIChE, 31, 365-389 (1935).

Hinze, J. O. Fundamentals of the hydrodynamic mechanism of splitting in dispersion processes. AIChE Journal, 1, 289-295 (1955). https://doi. org/10.1002/aic.690010303

Inc, A. Ansys Fluent Theory Guide, In ANSYS, Inc Canonsburg (2013).

Joosten, G. E. H., Schilder, J. G. M., Janssen, J. J. The influence of suspended solid material on the gasliquid mass transfer in stirred gas-liquid contactors. Chemical Engineering Science, 32, 563-566 (1977). https://doi.org/10.1016/0009-2509(77)87017-6

Karimi, A., Golbabaei, F., Mehrnia, M. R., Neghab, M., Mohammad, K., Nikpey, A., Pourmand, M. R. Oxygen mass transfer in a stirred tank bioreactor using different impeller configurations for environmental purposes. Iranian Journal of Environmental Health Sciences and Engineering, 10, 1-9 (2013). https://doi.org/10.1186/1735-2746$10-1$

Kerdouss, F., Bannari, A., Proulx, P., Bannari, R., Skrga, M., Labrecque, Y. Two-phase mass transfer coefficient prediction in stirred vessel with a CFD model. Computers and Chemical Engineering, 32, 1943-1955 (2008). https://doi.org/10.1016/j. compchemeng.2007.10.010

Khopkar, A. R., Aubin, J., Xuereb, C., Sauze, N. Le, Bertrand, J., Ranade, V. V. Gas-Liquid Flow Generated by a Pitched-Blade Turbine: Particle Image Velocimetry Measurements and Computational Fluid Dynamics Simulations. Industrial and Engineering Chemistry Research, 42, 5318-5332 (2003). https://doi.org/10.1021/ ie020954t

Khopkar, A. R., Rammohan, A. R., Ranade, V. V., Dudukovic, M. P. Gas-liquid flow generated by a Rushton turbine in stirred vessel: CARPT/CT measurements and CFD simulations. Chemical Engineering Science, 60, 2215-2229 (2005). https://doi.org/10.1016/j.ces.2004.11.044

Khopkar, A. R., Ranade, V. V. CFD simulation of gas-liquid stirred vessel: VC, S33, and L33 flow regimes. American Institute Of Chemical Engineers, 52, 1654-1672 (2006). https://doi. org/10.1002/aic.10762

Ljungqvist, M., Rasmuson, A. Numerical Simulation of the Two-Phase Flow in an Axially Stirred Vessel. Chemical Engineering Research and Design, 79, 533-546 (2001). https://doi. org/10.1205/02638760152424307 
Martín, M., Montes, F. J., Galán, M. A. Bubbling process in stirred tank reactors II: Agitator effect on the mass transfer rates. Chemical Engineering Science, 63, 3223-3234 (2008). https://doi. org/10.1016/j.ces.2008.03.035

Montante, G., Micale, G., Magelli, F., Brucato, A. Experiments and CFD Predictions of Solid Particle Distribution in a Vessel Agitated with Four Pitched Blade Turbines. Chemical Engineering Research and Design, 79, 1005-1010 (2001). https://doi. org $/ 10.1205 / 02638760152721253$

Murthy, B. N., Ghadge, R. S., Joshi, J. B. CFD simulations of gas-liquid-solid stirred reactor: Prediction of critical impeller speed for solid suspension. Chemical Engineering Science, 62, 7184-7195 (2007). https://doi.org/10.1016/j. ces.2007.07.005

Nedeltchev, S. Correction of the Penetration Theory Applied for Prediction of Mass Transfer Coefficients in a High-Pressure Bubble Column Operated with Gasoline and Toluene. Journal of Chemical Engineering of Japan, 36, 630-633 (2003). https://doi.org/10.1252/jcej.36.630

Nemati, M., Harrison, S. T. L., Hansford, G. S., Webb, C. Biological oxidation of ferrous sulphate by Thiobacillus ferrooxidans: a review on the kinetic aspects. Biochemical Engineering Journal, 1, 171-190 (1998). https://doi.org/10.1016/S1369703X(98)00006-0

Panneerselvam, R., Savithri, S., Surender, G. D. CFD modeling of gas-liquid-solid mechanically agitated contactor. Chemical Engineering Research and Design, 86, 1331-1344 (2008). https://doi. org/10.1016/j.cherd.2008.08.008

Scargiali, F., Busciglio, A., Grisafi, F., Brucato, A. Oxygen Transfer Performance of Unbaffled Stirred Vessels in View of Their Use as Biochemical Reactors for Animal Cell Growth. Chemical Engineering Transtions, 27, 205-210 (2012).

Scargiali, F., Busciglio, A., Grisafi, F., Brucato, A. Mass transfer and hydrodynamic characteristics of unbaffled stirred bio-reactors: Influence of impeller design. Biochemical Engineering Journal, 82, 41-47 (2014). https://doi.org/10.1016/j.bej.2013.11.009

Sedahmed, G. H., El-Taweel, Y. A., Abdel-Aziz, M. H., El-Naqeara, H. M. Mass and heat transfer enhancement at the wall of cylindrical agitated vessel by turbulence promoters. Chemical Engineering and Processing: Process Intensification, 80, 43-50 (2014). https://doi.org/10.1016/j.cep.2014.04.004

Shrihari, Kumar, R., Gandhi, K. S., Natarajan, K. A. Role of cell attachment in leaching of chalcopyrite mineral by Thiobacillus ferrooxidans. Applied Microbiology and Biotechnology, 36, 278-282 (1991). https://doi.org/10.1007/BF00164434

Wang, T., Wang, J. Numerical simulations of gas-liquid mass transfer in bubble columns with a CFD-PBM coupled model. Chemical Engineering Science, 62, 7107-7118 (2007). https://doi.org/10.1016/j. ces.2007.08.033

Xu, J. X., Wang, H., Wang, J. J., Wang, S. B., Zhu, D. F., Fan, G. F. CFD Simulation of Mixing Effects in Gas-Liquid-Solid Stirred Reactor Advanced Materials Research (2012). https://doi.org/10.4028/ www.scientific.net/AMR.383-390.5778

Yang, S., Li, X., Yang, C., Ma, B., Mao, Z.-S. Computational Fluid Dynamics Simulation and Experimental Measurement of Gas and Solid Holdup Distributions in a Gas-Liquid-Solid Stirred Reactor. Industrial and Engineering Chemistry Research, 55, 3276-3286 (2016). https://doi. org/10.1021/acs.iecr.5b03163

Zadghaffari, R., Moghaddas, J. S., Revstedt, J. A mixing study in a double-Rushton stirred tank. Computers and Chemical Engineering, 33, 1240-1246 (2009). https://doi.org/10.1016/j. compchemeng.2009.01.017

Zhang, Y., Bai, Y., Wang, H. CFD analysis of interphase forces in a bubble stirred vessel. Chemical Engineering Research and Design, 91, 29-35 (2013). https://doi.org/10.1016/j.cherd.2012.07.002

Zheng, C., Guo, J., Wang, C., Chen, Y., Zheng, H., Yan, Z., Chen, Q. Experimental study and simulation of a three-phase flow stirred bioreactor. Chinese Journal of Chemical Engineering, 27, 649-659 (2019). https://doi.org/10.1016/j.cjche.2018.06.010

Zheng, C., Huang, Y., Guo, J., Cai, R., Zheng, H., Lin, C., Chen, Q. Investigation of cleaner sulfide mineral oxidation technology: Simulation and evaluation of stirred bioreactors for gold-bioleaching process. Journal of Cleaner Production, 192, 364-375 (2018). https://doi.org/10.1016/j.jclepro.2018.04.172 
